\title{
Remediation of organochlorine pesticides contaminated soil using thermal plasma
}

\section{Dovilè Gimžauskaitė ${ }^{1}$}

Andrius Tamošiūnas ${ }^{1}$,

Simona Tučkute் ${ }^{1}$,

Diana Meilutytė-Lukauskiené $\dot{1}^{1,2}$,

Mindaugas Aikas ${ }^{1}$,

Rolandas Uscila ${ }^{1}$

Justas Samosionokas ${ }^{3}$

${ }^{1}$ Lithuanian Energy Institute,

Breslaujos St. 3,

44403 Kaunas, Lithuania

Email: Dovile.Gimzauskaite@lei.lt

${ }^{2}$ Lithuanian University of Health Sciences,

A. Mickevičiaus St. 9 ,

44307 Kaunas, Lithuania

${ }^{3}$ Public Agency

"Soil Remediation Technologies",

Antakalnio St. 42,

10304 Vilnius, Lithuania
Organochlorine pesticides have been used widely in agriculture for effective pest control. However, organochlorine pesticides such as dichloro-diphenyl-trichloroethane (DDT) contaminate soil, groundwater and cause carcinogenic effects, reproductive disorders for birds, humans and other mammals. Consequently, the use of DDT in agriculture has been gradually forbidden since 1972. Nevertheless, due to the long halflife of DDT ( $\sim 36$ years), its residues are still present in the soil. Therefore, there is a need to find a method for the treatment of this dangerous contaminant in the soil. This experimental research is aimed to analyse thermal air and water vapour plasmas eligibility to remediate soil contaminated by organochlorine pesticides (mainly DDT). Hence, parameters of the polluted soil were investigated before and after the treatment with thermal plasma using scanning electron microscopy (SEM), an optical microscope, a photo camera, energy dispersive X-ray spectroscopy (EDX) and gas chromatography-mass spectrometry (GC-MS). SEM analysis revealed that interaction of polluted soil with thermal air plasma or water vapour plasma caused structural changes of the soil. EDX data demonstrated complete removal of chlorine after the soil cleaning with plasmas. Moreover, the measurements performed with GCMS confirmed that organochlorine pesticides concentrations in the soil were reduced noticeably after the soil cleaning with thermal plasmas. Thus, experimental results indicate that contaminated soil treatment using thermal air or water vapour plasma has satisfactory pesticides degradation capacity.

Keywords: thermal plasma, organochlorine pesticides, soil remediation

\section{INTRODUCTION}

Pesticides are used in agriculture to prevent or control pests, weeds and to reduce or eliminate yield loses, as well as keep high product quality $[1,2]$. Also, pesticides can be utilised to prevent or control diseases, including malaria, yellow fe- ver, filariasis, dengue $[3,4]$. The use of pesticides sharply increased after the Second World War, and it helped to raise agricultural productivity, economy and fight with the disease [5, 6]. However, after some time, scientists realised that part of the pesticides have low water solubility, low volatility and resists natural degradation. Thus, they 
are persistent in the environment [7, 8]. High concentrations of pesticides can cause harm to wildlife, humans and in general terms a variety of ecosystems. Such pesticides are classified as persistent organic pollutants (POPs) and are listed in the Stockholm Convention on POPs. Aldrin, endosulfan, dichloro-diphenyl-trichloroethane (DDT), alpha-hexachloro-cyclohexane $(\alpha-\mathrm{HCH})$, beta-hexachloro-cyclohexane $(\beta-\mathrm{HCH})$, lindane $(\gamma-\mathrm{HCH})$ commonly known as organochlorine pesticides (OCP) belong to persistent organic pollutants $[9,10]$.

Moreover, the United States Environmental Protection Agency (USEPA) has classified DDT and its metabolites, dichloro-diphenyl-dichloroethylene (DDE), dichloro-diphenyl-dichloroethane (DDD) as priority pollutants and banned its use $[11,12]$. DDT was widely produced, used and still is a very well known pesticide worldwide. Even though dichloro-diphenyl-trichloroethane has been gradually banned since 1972, its residues still exist in the environment (e.g. soil, water). Accordingly, DDT has a long dissipation half-life ( $\sim 36$ years) in the soil $[13,14]$. Soil contamination with DDT is an environmental issue not only due to the high sorption of organochlorine pesticides onto the soil matrix, but also because of continuous desorption from the soil matrix that causes secondary pollution of the atmosphere and water $[13,15-$ 17]. Therefore, it is imperative to find a remediation method which enables to remove organochlorine pesticides from the soil completely. Hence, different soil remediation methods based on biological (e.g. phytoremediation), chemical (e.g. catalytic de-chlorination), physical (e.g. soil excavation), thermal (e.g. incineration) processes have been utilised for the elimination of pesticides from the soil. However, these methods had drawbacks, including long treatment time, strong dependence on environmental conditions, generation of toxic by-products, incomplete degradation of pesticides, limited penetration of reagents within the soil matrix [18-21].

Consequently, plasma technologies are progressively becoming the focus of research studies on remediation of pesticides contaminated soil $[6,22-$ 27]. Recently, Ma et al. [22] have presented one of the newest research about the non-thermal pulsed corona discharge plasma usage for the treatment of vaporised DDT. The degradation efficiency of DDT varied from $56.3 \%$ to $94.2 \%$ depending on the used air temperature, energy density, oxygen content and humidity. Wang et al. [23] used the same type of plasma for the degradation of pentachlorophenol (PCP) in the soil. The researchers stated that $87 \%$ of pentachlorophenol was remediated from the soil within 60 minutes. Later on, Wang et al. [24] were investigating the influence of the plasma forming gas type on the PCP contaminated soil remediation process. They pointed out that after 45 minutes of the soil treatment, the degradation efficiency of pentachlorophenol was equal to $92 \%$, $77 \%, 19 \%$ and $8 \%$ in the oxygen, air, argon and nitrogen atmospheres, respectively.

Lately, non-thermal plasma was applied for the neutralisation of pesticides. Based on the above-presented experimental results, this type of plasma does not provide complete neutralisation of pesticides. Meanwhile, thermal plasma has the potential to completely degrade pesticides due to its specific features, including a higher concentration of active plasma species and higher temperature compared to non-thermal plasma. Also, the soil remediation with thermal plasma is fast in time, and it does not require soil pre-treatment or additional materials/reagents. Additionally, there is no limit on the state of matter or the concentration of the pollutant.

Moreover, the efficiency of pesticides degradation strongly depends on the type of plasma forming gas. The major radicals of water vapour plasma $(\mathrm{OH}, \mathrm{H})$ and air plasma $(\mathrm{O})$ are considered to be one of the most reactive radicals that trigger and accelerate degradation reactions of the pollutants. Hence, the purpose of this experimental study was to analyse thermal air and water vapour plasmas eligibility to remediate soil contaminated by organochlorine pesticides, which are added in the Stockholm Convention POPs list.

\section{METHODOLOGY}

The types of organochlorine pesticides with whom the soil was contaminated are presented in Table 1. The plasma chemical reactor used for the remediation of the soil polluted by organochlorine pesticides is presented in Fig. 1. 
Firstly, the contaminated soil was sifted through a $2 \mathrm{~mm}$ mesh to eliminate debris, and then the soil was treated with air plasma or water vapour plasma. The interaction between polluted soil and thermal plasma was carried out under atmospheric pressure for thirty minutes. When the air was used as a plasma forming gas, the power of the plasmatron was $52.8 \mathrm{~kW}$ at an air flow rate of $4.9 \mathrm{~g} / \mathrm{s}$. The average temperature of air plasma system was $2400 \mathrm{~K}$. In the case with water vapour plasma, the power of plasmatron was equal to $56 \mathrm{~kW}$, and water vapour flow rate was equal to $3.8 \mathrm{~g} / \mathrm{s}$. The mean temperature of the water vapour plasma system was equal to $2800 \mathrm{~K}$.

Soil analysis was done before and after the remediation with thermal plasmas. Soil surface morphology of organochlorine pesticides contaminated soil and soil cleaned with plasma was studied by a scanning electron microscope (SEM, Hitachi S-3400N), an optical microscope (Olympus BX 51) and a photo camera (NICON D90). Energy dispersive X-ray spectroscopy (EDX, Bruker Quad 0540) was used to identify the elemental composition of soil polluted by pesticides as well as cleaned soil. The organochlorine pesticides concentrations in the contaminated and plasma remediated soil were measured by gas chromatography-mass spectrometry (GC-MS).

Table 1. Types of organochlorine pesticides with whom the soil was contaminated

\begin{tabular}{ccc}
\hline \multicolumn{3}{c}{ Types of organochlorine pesticides } \\
\hline $\begin{array}{c}\text { Dichloro-diphenyl- } \\
\text { trichloroethane }\end{array}$ & Abbreviation & $\begin{array}{c}\text { Chemical } \\
\text { formula }\end{array}$ \\
\hline $\begin{array}{c}\text { Dichloro-diphenyl- } \\
\text { dichloroethylene }\end{array}$ & DDT & $\mathrm{C}_{14} \mathrm{H}_{9} \mathrm{Cl}_{5}$ \\
\hline $\begin{array}{c}\text { Dichloro-diphenyl- } \\
\text { dichloroethane }\end{array}$ & DDD & $\mathrm{C}_{14} \mathrm{H}_{8} \mathrm{Cl}_{4}$ \\
\hline $\begin{array}{c}\text { alpha-Hexachloro- } \\
\text { cyclohexane }\end{array}$ & $(\mathrm{C}-\mathrm{HCH})$ & $\mathrm{C}_{10} \mathrm{Cl}_{6} \mathrm{Cl}_{6}$ \\
\hline $\begin{array}{c}\text { beta-Hexachloro- } \\
\text { cyclohexane }\end{array}$ & $(\beta-\mathrm{HCH})$ & $\mathrm{C}_{6} \mathrm{H}_{6} \mathrm{Cl}_{6}$ \\
\hline $\begin{array}{c}\text { gamma-Hexachloro- } \\
\text { cyclohexane, or lindane }\end{array}$ & $(\gamma-\mathrm{HCH})$ & $\mathrm{C}_{6} \mathrm{H}_{6} \mathrm{Cl}_{6}$ \\
\hline $\begin{array}{c}\text { delta-Hexachloro- } \\
\text { cyclohexane }\end{array}$ & $(\delta-\mathrm{HCH})$ & $\mathrm{C}_{6} \mathrm{H}_{6} \mathrm{Cl}_{6}$ \\
\hline
\end{tabular}

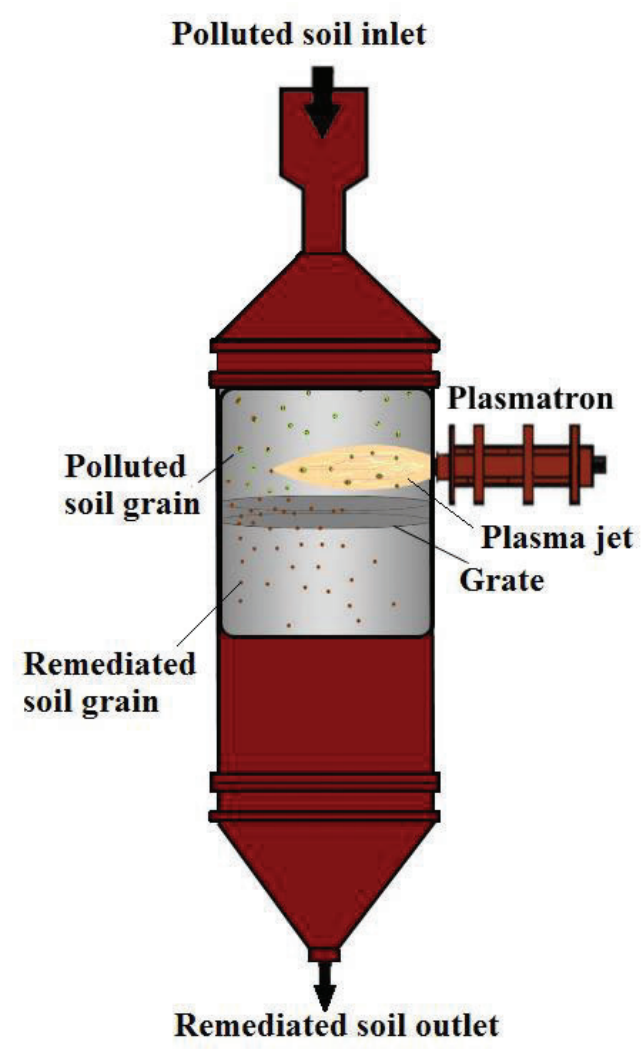

Fig. 1. The plasma chemical reactor used for polluted soil remediation [28]

\section{RESULTS AND DISCUSSION}

Soil colour changes before and after treatment with thermal plasma were analysed with optical microscopy, photo camera and results presented in Fig. 2. Before the remediation process, the soil was darker compared to treated soil and contained green particles which correspond to pesticides. After interaction with thermal plasma, the soil became lighter brown with a reddish tint. This tint is a feature of trivalent ferric compounds. The darker colour of polluted soil was caused by a small number of humic compounds (carbon) in the soil. Generally, humic compounds cause black or brown soil colour. The colour tint depends on the concentration of carbon in the soil. During the reaction among soil and thermal plasma, the decomposition and evaporation of humic compounds in the soil appeared. This process caused the brightening of soil colour. Also, the redness caused by iron compounds in the soil come to the fore due to the carbon reduction in the soil. 

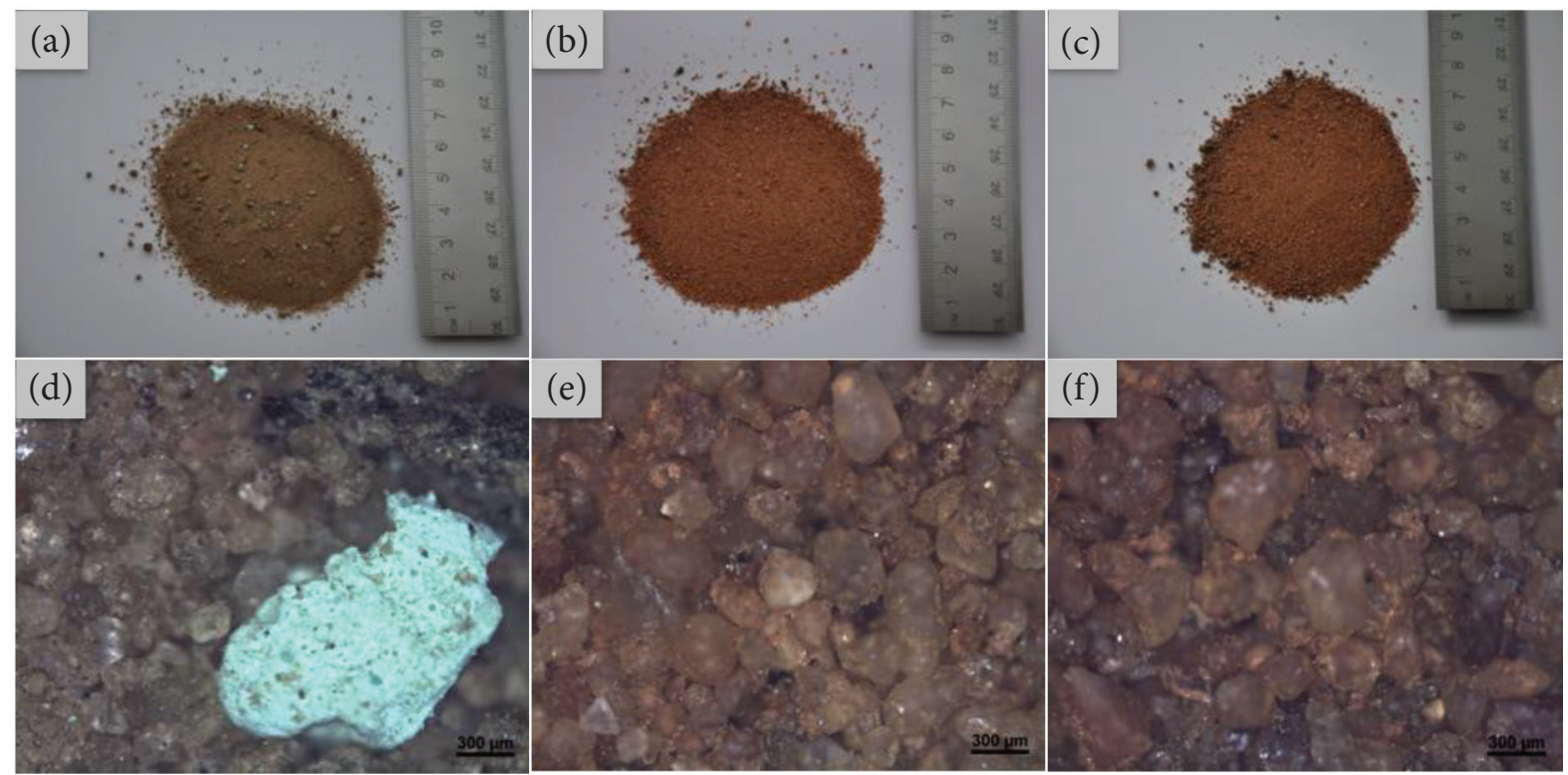

Fig. 2. Soil: (a), (d) - contaminated by organochlorine pesticides (green particles - pesticides), (b), (e) - after treatment with air plasma, (c), (f) - after treatment with water vapour plasma. Figure 2 (a), (b) and (c) were taken with a photo camera, while Fig. 2 (d), (e) and (f) were taken with an optical microscope

\section{Contaminated soil analysis with SEM}

Surface morphology of soil contaminated by organochlorine pesticides and soil cleaned with thermal plasma was analysed by a scanning electron microscope (Fig. 3). All soil samples have a granular structure and consist of approximately uniform size particles (Fig. 3a, c, e). Nevertheless, contaminated soil has a relatively rough surface (Fig. 3b), while soil remediated with thermal plasma has a relatively smoother surface (Fig. 3 d, e). The pesticides impurity in the soil can influence the roughness of polluted soil surface. Surface morphology of the organochlorine pesticide particle is shown in Fig. 4. The pesticide is constituted of irregularly-shaped agglomerates with a comparatively rough surface. Thus, pesticides possibly affected surface morphology of polluted soil.

\section{Contaminated soil analysis with EDX}

Elemental composition of organochlorine pesticide particle is summarised in Table 2. It is known that chlorine, carbon and hydrogen molecules compose organochlorine pesticides (Table 1). Consequently, pesticide analysis carried out by energy dispersive X-ray spectroscopy (EDX) indicated that the concentrations of chlorine and carbon in the pesticide particle are
Table 2. Elemental composition of organochlorine pesticide particle

\begin{tabular}{c|c}
\hline \multirow{2}{*}{ Element } & Pesticide particle \\
\cline { 2 - 2 } & Concentration, at \% \\
\hline $\mathrm{C}$ & 3.13 \\
\hline $\mathrm{O}$ & 37.44 \\
\hline $\mathrm{Si}$ & 2.94 \\
\hline $\mathrm{Cl}$ & 13.71 \\
\hline $\mathrm{Cu}$ & 36.31 \\
\hline $\mathrm{K}$ & 0.25 \\
\hline $\mathrm{Ca}$ & 3.13 \\
\hline $\mathrm{Mg}$ & 0.07 \\
\hline $\mathrm{Al}$ & 1.86 \\
\hline $\mathrm{Fe}$ & 0.83 \\
\hline $\mathrm{S}$ & 0.27 \\
\hline $\mathrm{P}$ & 0.06 \\
\hline
\end{tabular}

equal to $13.71 \%$ and $3.13 \%$, respectively. However, EDX cannot detect hydrogen.

Additionally, a significant part of the sample elemental composition is formed by copper (36.31\%), oxygen (37.44\%) and calcium (3.13\%). Hence, copper-based compounds are commonly used as pesticides (e.g. fungicides, herbicides, algicides) [29]. Bordeaux mixture $-\mathrm{Cu}(\mathrm{OH})_{2} \mathrm{CaSO}_{4}$ is a widely used fungicide. The combination of 

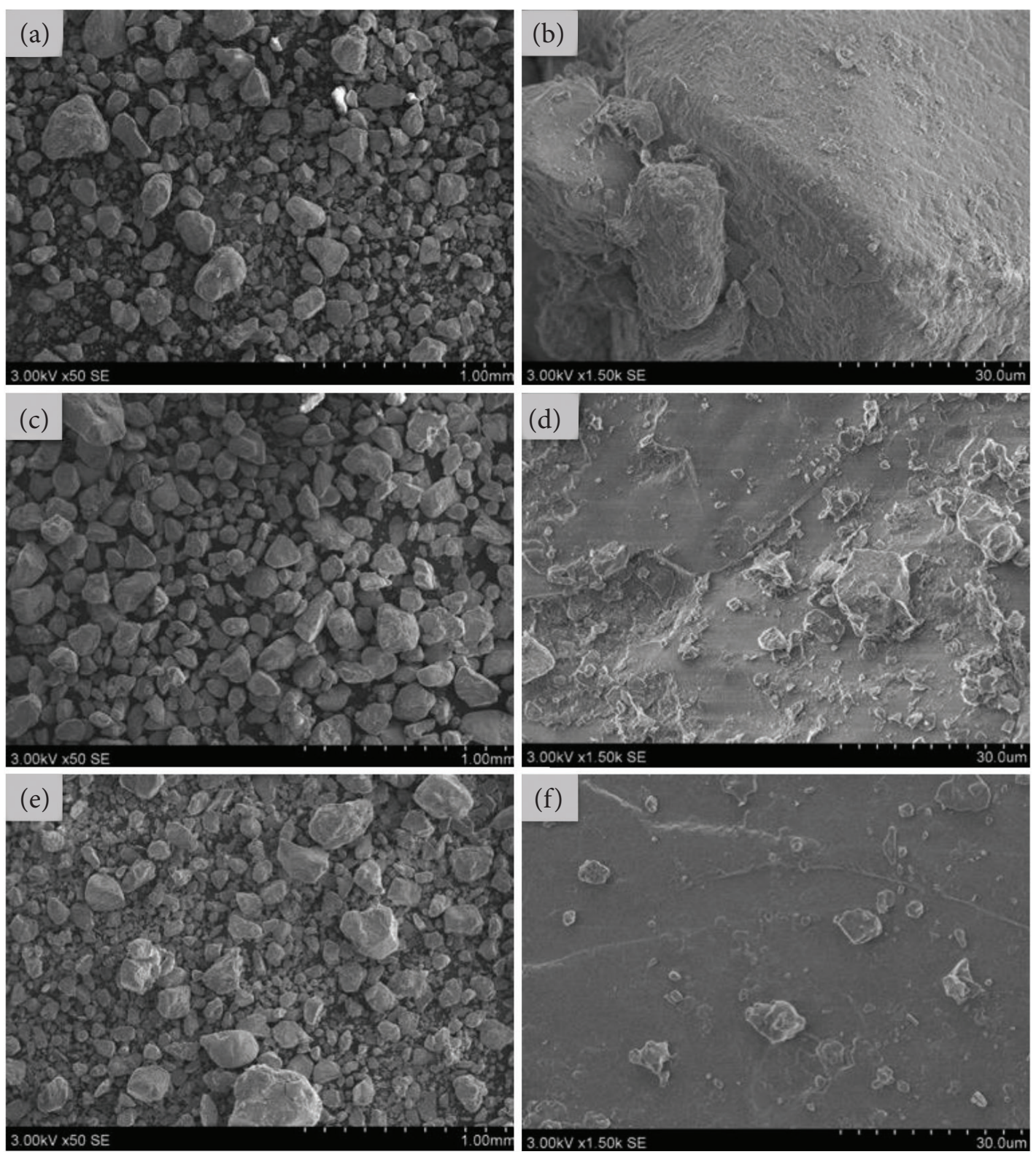

Fig. 3. SEM surface views of soil: (a), (b) - soil polluted by organochlorine pesticides, (c), (d) - soil cleaned with air plasma, (e), (f) - soil cleaned with water vapour plasma
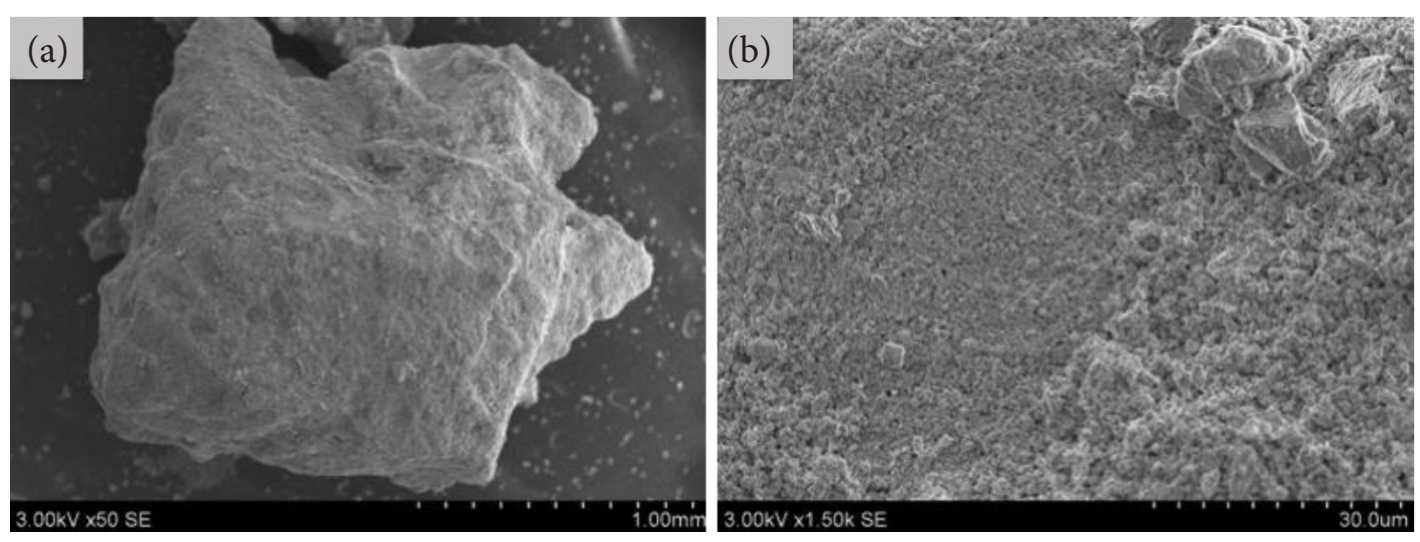

Fig. 4. SEM surface views of organochlorine pesticide particle 
Bordeaux mixture and DDT was used often because it increased harvest in agriculture [30]. Consequently, it allows assuming that soil was contaminated with the mix of organochlorine pesticides and Bordeaux mixture. As a result of this, high concentrations of copper, oxygen and calcium came from $\mathrm{Cu}(\mathrm{OH})_{2} \mathrm{CaSO}_{4}$. Moreover, Bordeaux mixture has a green colour. Also, copper compounds during interaction with the environment (air, oxygen, water) form a green outer layer. These green particles can be seen in contaminated soil (Fig. 2a).

Elemental composition of the soil before and after remediation with thermal plasma is presented in Table 3. Contaminated soil consisted of $0.14 \%$ of chlorine, whereas after interaction with air plasma or water vapour plasma, chlorine was not detected at all. Also, the changes in carbon concentration in the soil were observed. Before the remediation process, the carbon content in the soil was equal to $17.35 \%$. After cleaning with air plasma and water vapour plasma, it decreased to $8.92 \%$ and $7.98 \%$, respectively. Thus, soil remediation with thermal plasma showed a noticeable change in chlorine and carbon concentrations. Since organochlorine pesticides consist of carbon, hydrogen and chlorine molecules, this takes to the presumption that via the remediation process, conversion of organochlorine pesticides took place. Also, the gasification process, which occurred during an interaction between contaminated soil and thermal plasma caused the decomposition and evaporation of natural carbon in the soil. Consequently, the decrease in total carbon content in the soil was observed.

\section{Gas chromatography-mass spectrometry results}

The organochlorine pesticides concentrations in the contaminated and plasma treated soil are shown in Table 4. The initial concentrations of alpha- $\mathrm{HCH}$, delta- $\mathrm{HCH}$, lindane (gamma- $\mathrm{HCH}$ ), beta-HCH, 4,4'-DDE and 4,4'-DDD were equal to $19.8 \mu \mathrm{g} / \mathrm{kg}, 360 \mu \mathrm{g} / \mathrm{kg}, 15.1 \mu \mathrm{g} / \mathrm{kg}, 99.4 \mu \mathrm{g} / \mathrm{kg}$, $89.4 \mu \mathrm{g} / \mathrm{kg}$ and $137 \mu \mathrm{g} / \mathrm{kg}$, respectively. Moreover, 4,4'-DDT formed the highest - $1569 \mu \mathrm{g} / \mathrm{kg}$ concentration in the soil. After soil cleaning with air plasma or water vapour plasma, the concentrations of organochlorine pesticides in the soil decreased to negligible values of $<3.0-5.0 \mu \mathrm{g} / \mathrm{kg}$. Therefore, the notable reduction of organochlorine pesticides in the soil indicates that thermal plasma has satisfactory pesticides degradation capacity and is suitable to remediate polluted soil.

Moreover, the significant difference between treatmentresultsobtainedwithairplasmaandwater vapour plasma was not found. Both thermal plasmas are capable of remediating soil contaminated

Table 3. Elemental composition of organochlorine pesticides contaminated and plasma cleaned soil

\begin{tabular}{c|c|c|c}
\hline \multirow{2}{*}{ Element } & $\begin{array}{c}\text { Soil polluted with organochlorine } \\
\text { pesticides }\end{array}$ & Soil treated with air plasma & $\begin{array}{c}\text { Soil treated with water vapour } \\
\text { plasma }\end{array}$ \\
\cline { 2 - 4 } Concentration, at \% & Concentration, at \% & Concentration, at \% \\
\hline $\mathrm{O}$ & 17.35 & 8.92 & 7.98 \\
\hline $\mathrm{Si}$ & 56.94 & 59.64 & 59.34 \\
\hline $\mathrm{Cl}$ & 18.11 & 21.89 & 23.79 \\
\hline $\mathrm{K}$ & 0.14 & not detected & 1.33 \\
\hline $\mathrm{Ca}$ & 0.92 & 1.52 & 0.41 \\
\hline $\mathrm{Mg}$ & 0.43 & 0.27 & 0.46 \\
\hline $\mathrm{Al}$ & 0.33 & 0.40 & 4.11 \\
\hline $\mathrm{Fe}$ & 3.53 & 4.72 & 1.28 \\
\hline $\mathrm{Na}$ & 0.93 & 1.09 & 0.46 \\
\hline $\mathrm{Ti}$ & 0.52 & 0.73 & 0.29 \\
\hline $\mathrm{P}$ & 0.26 & 0.23 & 0.20 \\
\hline $\mathrm{Cu}$ & 0.20 & 0.15 & 0.38 \\
\hline
\end{tabular}


Table 4. Organochlorine pesticides concentrations in the soil before and after remediation with thermal plasma

\begin{tabular}{c|c|c|c|c|c|c|c}
\hline & \multicolumn{7}{c}{ Organochlorine pesticides } \\
\cline { 2 - 8 } & (alpha-HCH) & (delta-HCH) & $\begin{array}{c}\text { Lindane } \\
\text { (gamma-HCH) }\end{array}$ & (beta-HCH) & $\mathbf{4 , 4 ^ { \prime } - \text { DDE }}$ & $\mathbf{4 , 4 ^ { \prime } - \text { DDD }}$ & $\mathbf{4 , 4 ^ { \prime } - \text { DDT }}$ \\
\cline { 2 - 8 } & $\boldsymbol{\mu g} / \mathbf{k g}$ & $\boldsymbol{\mu g} / \mathbf{k g}$ & $\boldsymbol{\mu g} / \mathbf{k g}$ & $\boldsymbol{\mu g} / \mathbf{k g}$ & $\boldsymbol{\mu g} / \mathbf{k g}$ & $\boldsymbol{\mu g} / \mathbf{k g}$ & $\boldsymbol{\mu g} / \mathbf{k g}$ \\
\hline $\begin{array}{c}\text { Soil polluted with or- } \\
\text { ganochlorine pesticides }\end{array}$ & 19.8 & 360 & 15.1 & 99.4 & 89.4 & 137 & 1569 \\
\hline $\begin{array}{c}\text { Soil treated with water } \\
\text { vapour plasma }\end{array}$ & $<4.0$ & $<3.0$ & $<4.0$ & $<4.0$ & $<3.0$ & $<4.0$ & $<5.0$ \\
\hline $\begin{array}{c}\text { Soil treated with air } \\
\text { plasma }\end{array}$ & $<4.0$ & $<3.0$ & $<4.0$ & $<4.0$ & $<3.0$ & $<4.0$ & $<5.0$ \\
\hline
\end{tabular}

by organochlorine pesticides. However, the air as a plasma forming gas is easily accessible and usable [31]. Also, the air plasma-chemical remediation system is slightly simpler compared to the water vapour system which needs a steam generator and a superheater. Accordingly, the use of air as a plasma forming gas should be preferred.

\section{CONCLUSIONS}

In this experimental research, remediation of organochlorine pesticides contaminated soil was carried out by using air plasma and water vapour plasma.

Scanning electron microscope data showed soil surface morphology changes after interaction with thermal plasmas. Before the remediation process, the soil surface was relatively rough. After treatment, it became relatively smooth. The roughness of the contaminated soil surface possibly was influenced by pesticides, as it also has a rough surface morphology.

Measurements carried out by energy dispersive $\mathrm{X}$-ray spectroscopy revealed a reduction of the main components of the organochlorine pesticides - chlorine and carbon in the soil after remediation with thermal plasmas. Chlorine was not found at all. The carbon concentration decreased from $17.35 \%$ to $8.92 \%$ and $7.98 \%$ after reaction with air plasma and water vapour plasma, respectively.

Measurements taken with gas chromatography-mass spectrometry indicated a significant reduction of organochlorine pesticides in the soil after remediation with thermal plasmas. The main contaminant - DDT concentration in the polluted soil was equal to $1569 \mu \mathrm{g} / \mathrm{kg}$, after treatment with plasmas, it decreased to a negligible value of $<3.0-5.0 \mu \mathrm{g} / \mathrm{kg}$.

A significant decrease of organochlorine pesticides in the soil after the remediation process shows that thermal plasma has satisfactory pesticides degradation capacity and is appropriate to treat contaminated soil.

\section{ACKNOWLEDGEMENTS}

The authors are grateful to Dr. D. Milčius, the Head of the Center for Hydrogen Energy Technologies of Lithuanian Energy Institute, for the experimental facilities used to perform this work.

Received 27 May 2019 Accepted 3 September 2019

\section{References}

1. Cycon M., Mrozik A., Piotrowska-Seget Z. Bioaugmentation as a strategy for the remediation of pesticide-polluted soil: A review. Chemosphere. 2017. Vol. 172. P. 52-71.

2. Všíčková J., Hvezdová M., Kosubová P., Hofman J. Ecological risk assessment of pesticide residues in arable soils of the Czech Republic. Chemosphere. 2019. Vol. 216. P. 479-487.

3. World Health Organisation. Pesticides and their application for the control of vectors and pests of public health importance. WHO/CDS/NTD/ WHOPES/GCDPP. 2012. 114 p.

4. Rivero A., Vézilier J., Weill M., Read A. F., Gandon S. Insecticide control of vector-borne diseases: When is insecticide resistance a problem? PLoS Pathogens. 2010. Vol. 6. P. 1-9. 
5. Li Z. Health risk characterization of maximum legal exposures for persistent organic pollutant (POP) pesticides in residential soil: An analysis. Journal of Environmental Management. 2018. Vol. 205. P. 163-173.

6. Castelo-Grande T., Augusto P. A., Monteiro P., Estevez A. M., Barbosa D. Remediation of soils contaminated with pesticides: a review. International Journal of Environmental Analytical Chemistry. 2010. Vol. 90. P. 438-467.

7. Bocos E., Fernández-Costas C., Pazos M., Sanromán M. Á. Removal of PAHs and pesticides from polluted soils by enhanced electrokinetic-Fenton treatment. Chemosphere. 2015. Vol. 125. P. 168-174.

8. El-Shahawi M. S., Hamza A., Bashammakh A. S., Al-Saggaf W. T. An overview on the accumulation, distribution, transformations, toxicity and analytical methods for the monitoring of persistent organic pollutants. Talanta. 2010. Vol. 80. P. 1587-1597.

9. Fang Y., Nie Z., Die Q., Tian Y., Liu F., Hh J., Huang Q. Organochlorine pesticides in soil, air, and vegetation at and around a contaminated site in southwestern China: Concentration, transmission, and risk evaluation. Chemosphere. 2017. Vol. 178. P. 340-349.

10. UNEP. Stockholm Convention on Persistent Organic Pollutants (POPs). Sweden, 2001. 64 p.

11. Wagoner E. R., Karty J. A., Peters D. G. Catalytic reduction of 4,40-(2,2,2-trichloroethane-1,1diyl)bis (chlorobenzene) (DDT) with nickel(I) salen electrogenerated at vitreous carbon cathodes in dimethylformamide. Journal of Electroanalytical Chemistry. 2013. Vol. 706. P. 55-63.

12. Ma X., Liu S., Liu Y., Li Q., Gu G., Xia C. New insights into the effect of base on the dechlorination of DDT in T isopropanol-water over Pd/C catalyst under mild conditions. Chemical Engineering Journal. 2018. Vol. 351. P. 756-765.

13. Balawejder M., Antos P., Czyjt-Kurylo S., Józefczyk R., Pieniazek M. A novel method for degradation of DDT in contaminated soil. Ozone: Science \& Engineering. 2014. Vol. 36. P. 166-173.

14. Zhao Y., Yi X., Li M., Liu L., Ma W. Biodegradation kinetics of DDT in soil under different environmental conditions by laccase extract from white rot fungi. Biotechnology and Bioengineer- ing, Chinese Journal of Chemical Engineering. 2010. Vol. 18. P. 486-492.

15. Zhang Y., Wong J. W. C., Zhao Z. Selvam A. Microemulsion-enhanced remediation of soils contaminated with organochlorine pesticides. Environmental Technology. 2011. Vol. 32. P. 1915-1922.

16. Ahmed S. M., Taha M. R., Taha O. M. E. Kinetics and isotherms of dichlorodiphenyltrichloroethane (DDT) adsorption using soil-zeolite mixture. Nanotechnology for Environmental Engineering. 2018. Vol. 3. P. 1-20.

17. Villa R. D., Nogueira R. F. P. Oxidation of p, $\mathrm{p}^{\prime}$ DDT and p, $\mathrm{p}^{\prime}$-DDE in highly and long-term contaminated soil using Fenton reaction in a slurry system. Science of the Total Environment. 2006. Vol. 371. P. 11-18.

18. Morillo E., Villaverde J. Advanced technologies for the remediation of pesticide-contaminated soils. Science of the Total Environment. 2017. Vol. 586. P. 576-597.

19. Takayama M., Ebihara K., Stryczewska H., Ikegami T., Gyoutoku Y., Kubo K., Tachibana M. Ozone generation by dielectric barrier discharge for soil sterilization. Thin Solid Films. 2006. Vol. 506-507. P. 396-399.

20. Purnomo A. S., Mori T., Kondo R. Involvement of Fenton reaction in DDT degradation by brown-rot fungi. International Biodeterioration \& Biodegradation. 2010. Vol. 64. P. 560-565.

21. Wang H., Zhou G., Guo H., Ge Z., Yi C. Organic compounds removal in soil in a seven-needleto-net pulsed discharge plasma system. Journal of Electrostatics. 2016. Vol. 80. P. 69-75.

22. Ma F., Zhu Y., Wu B., Zhang Q., Xu D., Xu J., Wang B., Gu Q., Li F. Degradation of DDTs in thermal desorption off-gas by pulsed corona discharge plasma. Chemosphere. 2019. Vol. 233. P. 913-919.

23. Wang T. C., Lu N., Li J., Wu Y. Evaluation of the potential of pentachlorophenol degradation in soil by pulsed corona discharge plasma from soil characteristics. Environmental Science \& Technology. 2010. Vol. 44. P. 3105-3110.

24. Wang T. C., Lu N., Li J., Wu Y. Degradation of pentachlorophenol in soil by pulsed corona discharge plasma. Journal of Hazardous Materials. 2010. Vol. 180. P. 436-441. 
25. Wang T., Ren J., Qu G., Liang D., Hu S. Glyphosate contaminated soil remediation by atmospheric pressure dielectric barrier discharge plasma and its residual toxicity evaluation. Journal of Hazardous Materials. 2016. Vol. 320. P. 539-546.

26. Bai Y., Chen J., Yang Y., Guo L., Zhang C. Degradation of organophosphorus pesticide induced by oxygen plasma: Effects of operating parameters and reaction mechanisms. Chemosphere. 2010. Vol. 81. P. 408-414.

27. Bai Y., Chen J., Mu H., Zhang C., Li B. Reduction of dichlorvos and omethoate residues by $\mathrm{O}_{2}$ plasma treatment. Journal of Agricultural and Food Chemistry. 2009. Vol. 57. P. 6238-6245.

28. Gimžauskaitė D., Tamošiūnas A., Aikas M., Uscila R., Samosionokas J. The use of thermal plasma for the treatment of soil contaminated by petroleum hydrocarbons. Proceedings of 16th International Conference of Young Scientists on Energy Issues (CYSENI 2018), May 23-25, 2018, Kaunas, Lithuania. P. 286-292.

29. El-Gendy K. S., Radwan M. A., Gad A. F. In vivo evaluation of oxidative stress biomarkers in the land snail, Theba pisana exposed to copper-based pesticides. Chemosphere. 2009. Vol. 77. P. 339-344.

30. Bonde R., Snyder E. G. Comparison of different organic and copper fungicides and some combinations of fungicides with DDT for the control of potato diseases and insects. The American Potato Journal. 1946. Vol. 23. P. 415-425.

31. Zhang H., Ma D., Qui R., Tang Y., Du C. Non-thermal plasma technology for organic contaminated soil remediation: A review. Chemical Engineering Journal. 2017. Vol. 313. P. 157-170.

Dovilè Gimžauskaitė, Andrius Tamošiūnas, Simona Tučkutè, Diana Meilutytè-Lukauskienė, Mindaugas Aikas, Rolandas Uscila, Justas Samosionokas

\section{CHLORO ORGANINIAIS PESTICIDAIS UŽTERŠTO GRUNTO VALYMAS TERMINE PLAZMA}

Santrauka

Dichloro-difenil-trichloroetanas (DDT), aldrinas, endosulfanas priskiriami chloro organiniams pesticidams (COP), kurie buvo plačiai naudojami žemès ūkyje kenkejjams naikinti. COP aplinkoje gali išlikti nepakitę ilgą laiką (pvz., DDT skilimo pusperiodis trunka apie 36 metus). Tokiu būdu grunte ar požeminiame vandenyje susikaupę didesni pesticidų kiekiai tampa tos terpès teršalais, trikdančiais ekosistemų veiklas ir galinčiais sukelti kancerogenini poveikį ar reprodukcinius sutrikimus paukščiams, žmonèms ir kitiems žinduoliams. Nors šių patvarių organinių junginių gamyba ir naudojimas buvo nutraukti arba bent jau apriboti $2001 \mathrm{~m}$. pasirašius Jungtinių Tautų Stokholmo konvenciją, tačiau jų sukeltos taršos židiniai (pvz., COP liekanos grunte) egzistuoja iki šiol. Siekiant panaikinti COP liekanas grunte, ieškoma tinkamiausių šių pavojingų teršalų išvalymo metodų.

Eksperimentinio tyrimo tikslas - ištirti terminès oro plazmos ir terminès vandens garo plazmos tinkamumą chloro organiniais pesticidais (daugiausia DDT $1569 \mu \mathrm{g} / \mathrm{kg}$ ) užterštam gruntui valyti. Gruntas buvo tiriamas prieš ir po valymo su termine plazma naudojant skenuojanti elektronini mikroskopą (SEM), optini mikroskopą, fotokamerą, rentgeno spindulių energijos spektroskopą (EDS) ir dujų chromatografą-masių spektrometrą (GC-MS). Su SEM gauti rezultatai parodè, kad sąveikos metu tarp užteršto grunto ir terminés oro plazmos, taip pat terminès vandens garo plazmos vyko grunto struktūriniai pokyčiai. EDS matavimai atskleidè, kad termine plazma išvalytame grunte nebuvo aptikta chloro. Matavimai, atlikti su GC-MS, patvirtino, kad chloro organinių pesticidų koncentracijos grunte po grunto valymo su termine plazma sumažèjo iki minimalių verčių $(<3,0-5,0 \mu \mathrm{g} / \mathrm{kg})$. Gauti eksperimentiniai rezultatai parodè, kad užteršto grunto valymas tiek termine oro plazma, tiek termine vandens garo plazma yra tinkami metodai pesticidų šalinimui iš grunto.

Raktažodžiai: terminè plazma, chloro organiniai pesticidai, grunto valymas 